\title{
INFLUENCE OF FOREIGN DIRECT INVESTMENT FLOWS ON THE COMPETITIVENESS OF THE CZECH REPUBLIC
}

\author{
Božena Plchová ${ }^{1}$, Kateřina Gajdušková ${ }^{2}$ \\ ${ }^{1}$ University of Economics, Prague, W. Churchill Sq. 4, 13067 Prague 3 \\ E-mail: bozena.plchova@vse.cz. \\ ${ }^{2}$ University of Economics, Prague, W. Churchill Sq. 4, 13067 Prague 3 \\ E-mail:xgajk03@vse.cz
}

\begin{abstract}
The article analyses inflow of foreign direct investment into the Czech Republic. It describes the development in recent years and analyses the influencing factors. Foreign direct investments are a very important financial source in the Czech economy and therefore much attention is paid to the factors which attract the inflow of foreign long-term and non-debt capital. It is important especially for investors during their decision making process of expanding the business abroad. Among others, the most important lures are openness of the country, low labour cost, the exchange rate policy and the overall risk of the country.
\end{abstract}

Keywords: Czech Republic, direct investment, exchange rate, labour, openness, risk, taxes.

JEL classification: F21, F23, F41

Doručeno redakci: 9.10.2012; Recenzováno: 14.4.2013; 14.4.2013; Schváleno k publikování: 11.9.2013

\section{Introduction}

The main objective of this article is based on the development of FDI flows in the Czech Republic. The Czech Republic is an open economy which is highly impacted by investment flows. Therefore the paper focuses on the relations between FDI flows of the Czech Republic and the influencing factors. The paper aims not only to analyse the development of investment flows and their structure, but also focuses on the competitiveness and ability of the country to attract new investment. It analyses all the determinants which influence the inward investment. In particular, it provides an overview of different approaches and empirical research in relation between the size and openness of the market, barriers, the exchange rate, the quality and cost of labour force and the overall risk of the country on one hand and the investment inflow on the other hand.

To cover all these points, the paper is divided into three chapters. The first chapter describes the development of the FDI flows in the Czech Republic; the second chapter is devoted to basic theoretical approaches and concepts that explain the changes in investment flows. The last chapter analyses the impact of the overall competitiveness of the country on the attractiveness for FDI.

Methodology of the paper is based on the quantitative comparison of the development of basic indicators. Firstly it describes the development of the foreign direct investment in the Czech Republic. Then it examines the main factors influencing the development. These factors are compared to conditions in other similar countries (according to the economic size, location or openness) like Bulgaria, Romania, Hungary, Poland, Slovenia, Slovakia and Germany. Because these countries are in some facts similar, the better or worse condition can be perceived as an advantage or disadvantage of the country for FDI flows. 


\section{Evolution of FDI in the Czech Republic}

Foreign direct investment represents specific investment across all financial flows that flow into and out of the country. It is such an investment, when an investor receives either an exclusive share of the business, $10 \%$ share in the equity of the company, $10 \%$ share in the voting rights or any other type of investment representing more than $10 \%$.This leads to the establishment, acquisition or expansion of permanent activities. The whole group of direct investment thus includes not only the initial transaction to the equity capital, but also all subsequent financial flows between companies, i.e. intercompany payables and receivables, or transfers of profits. It is interesting that foreign firms often reinvest their profits in the host country, which results in an increase in foreign direct investment as well (International Monetary Fund, 1995).

In the Czech Republic FDI represent a very important source of non-debt funding of current account deficit. Table 1shows the development of current and capital account deficit of the Czech Republic and its funding by foreign direct investment.

Table 1: Current account, net inflow of FDI and basic balance, mil. of EUR (1993-2010)

\begin{tabular}{|l|l|l|l|l|l|l|l|l|l|}
\hline $\begin{array}{l}\text { Account of } \\
\text { BP/Year }\end{array}$ & 1993 & 1994 & 1995 & 1996 & 1997 & 1998 & 1999 & 2000 & 2001 \\
\hline Current account & 376 & -652 & -1047 & -3255 & -3177 & -1139 & -1378 & -2961 & -3654 \\
\hline Capital account & 0 & 0 & 5 & 0 & 9 & 2 & -2 & -6 & -10 \\
\hline Net inflow of FDI & 478 & 626 & 1927 & 1007 & 1115 & 3201 & 5879 & 5357 & 6123 \\
\hline Basic balance & 854 & -26 & 885 & -2248 & -2053 & 2064 & 4499 & 2390 & 2459 \\
\hline & & & & & & & & & \\
\hline $\begin{array}{l}\text { Account of } \\
\text { BP/Year }\end{array}$ & 2002 & 2003 & 2004 & 2005 & 2006 & 2007 & 2008 & 2009 & 2010 \\
\hline Current account & -4442 & -5028 & -4650 & -1042 & -2391 & -5671 & -3297 & -3428 & -5894 \\
\hline Capital account & -4 & -3 & -458 & 185 & 351 & 795 & 1080 & 1936 & 1292 \\
\hline Net inflow of FDI & 8871 & 1693 & 3186 & 9365 & 3192 & 6480 & 1503 & 1397 & 3763 \\
\hline Basic balance & 4425 & -3338 & -1922 & 8508 & 1152 & 1604 & -714 & -95 & -839 \\
\hline
\end{tabular}

Source: Eurostat, Balance of Payments

Since 1998 the Czech Republic has been recording a massive inflow of investment from abroad, which successfully managed to offset the current account deficit. FDI were not able to cover these deficits only between 2003 and 2004, because deficits were of enormous proportions, while the inflow of FDI was not as strong as in previous years. The decrease in inflow was considerable especially in times of the financial and economic crisis - due to the high current account deficit and lower investment flows in years 2008-2010, the basic balance reached a deficit.

In recent years the Czech Republic has registered an enormous inflow of direct investment. The massive inflow of foreign capital was attracted by relatively cheap and educated workforce, low labour costs, a favorable location, an developed industrial sector as well as the government incentives. The investment flew to the new retail networks, warehouses, privatized public companies, new businesses and factories or extension of the existing ones, mainly in the manufacturing industry. In times of financial crisis, however, the non-debt source of funding was closed and there was a slowdown in activities creating new or expanding existing international business and an inflow of direct investment in the Czech Republic recorded a substantial decline. The reduction of direct investment led to external imbalances, to the trade balance deficits (or reduced surplus) and the negative income balance could not be completely financed by non-debt foreign capital. The decline in foreign 
investment, however, affected not only the external imbalance, but it also had the negative impact on the internal balance. Foreign investment in Central and Eastern Europe contributed significantly to the employment in the country and during the crisis, when foreign firms not only limited their new investments, but also reduced the activity of their existing subsidiaries the companies had to lay off many of their employees. Foreign-controlled enterprises also represented a significant share of the GDP and in case the crisis limited their activity, it had the negative impact on the development of basic economic indicators as well. The foreign direct investments will be in turn crucial for the establishment of new economic growth (Filippov and Kalotay, 2009; Kärkkäinen, 2008).

The Czech direct investment abroad is not so important as inbound investments, but they are gradually gaining in intensity (see Table 2). Since 2004 their volume has increased significantly and the Czech Republic annually invests over tens of billions to foreign companies and related transactions. However, given the significance and objectives of this article, attention will be paid mainly to the analysis of incoming investment.

Table 2: FDI flows abroad and in the Czech Republic (mil. EUR)

\begin{tabular}{|c|l|l|l|l|l|l|l|l|l|}
\hline FDI/Year & 1993 & 1994 & 1995 & 1996 & 1997 & 1998 & 1999 & 2000 & 2001 \\
\hline Abroad & 77 & 102 & 28 & 122 & 23 & 113 & 84 & 46 & 184 \\
\hline In the CR & 556 & 730 & 1955 & 1129 & 1139 & 3315 & 5963 & 5404 & 6308 \\
\hline & & & & & & & & & \\
\hline FDI/Year & 2002 & 2003 & 2004 & 2005 & 2006 & 2007 & 2008 & 2009 & 2010 \\
\hline Abroad & 221 & 184 & 824 & -12 & 1172 & 1187 & 2964 & 685 & 1283 \\
\hline In the CR & 9092 & 1877 & 4008 & 9353 & 4363 & 7667 & 4467 & 2082 & 5104 \\
\hline
\end{tabular}

Source: Eurostat, Balance of Payments

At the beginning FDI inflows to the Czech Republic accounted mostly for investment in equity (see Table 3). Over time and with the creation of foreign companies producing profit, the importance of reinvested earnings and other capital, which represented a financial transaction between the parent company and the subsidiary, began to grow significantly. On the contrary, investments in equity have been falling.

Table 3: Structure of the inflow of FDI in the Czech Republic (mil. EUR)

\begin{tabular}{|l|l|l|l|l|l|l|l|l|l|l|}
\hline $\begin{array}{l}\text { FDI } \\
\text { inflow/Year }\end{array}$ & 2001 & 2002 & 2003 & 2004 & 2005 & 2006 & 2007 & 2008 & 2009 & 2010 \\
\hline Equity capital & 3775 & 6755 & 444 & 1433 & 6176 & 1507 & 1836 & 791 & 720 & 1104 \\
\hline $\begin{array}{l}\text { Reinvested } \\
\text { earnings }\end{array}$ & 1695 & 2088 & 1431 & 2375 & 2624 & 3076 & 5063 & 1653 & 2561 & 3266 \\
\hline Other capital & 837 & 249 & -1 & 200 & 554 & -220 & 768 & 2024 & -1201 & 733 \\
\hline
\end{tabular}

Source: Eurostat, Balance of Payments

\section{Factors influencing Czech FDI}

The Czech Republic attracts mainly the type of investment called "efficiency seeking investments" (UNCTAD, 2009: pp. 8-9), focused on low costs and export. The analysis will therefore include the main factors representing the labour market and the size and openness of the economy. Subsequently, attention is paid to the other factors - barriers, the government measures and the risk.

\subsection{The size and openness of the economy}

Foreign-owned companies producing for the market of the host country are dependent on the size of its demand. A study from Price Waterhouse Coopers (2010, p. 4)proved that the higher 
the country's GDP per capita, the higher is the inflow of direct investment. This means that in the country there is a sufficient demand and the country is worth to establish a subsidiary.

The following Table 4 compares the evolution of this indicator in the Czech Republic to selected countries of the CEE and the EU-15. The CEE countries have much lower the GDP per capita than countries in West Europe, but they have more dynamic growth. Because of not so much purchasing power, they are not interesting for the market seeking investment, but the growth rate could be one of the points for their rise.

Table 4: GDP per capita (EUR)

\begin{tabular}{|l|l|l|l|l|l|l|l|l|l|l|}
\hline Country/Year & 2001 & 2002 & 2003 & 2004 & 2005 & 2006 & 2007 & 2008 & 2009 & 2010 \\
\hline EU 15 & 23900 & 24700 & 25000 & 26000 & 26700 & 28000 & 29300 & 29100 & 27500 & 28400 \\
\hline Bulgaria & 2000 & 2200 & 2400 & 2600 & 3000 & 3400 & 4000 & 4700 & 4600 & 4800 \\
\hline Czech Republic & 7000 & 8200 & 8300 & 9000 & 10200 & 11100 & 12300 & 14200 & 13100 & 14200 \\
\hline Hungary & 5800 & 6900 & 7300 & 8100 & 8800 & 8900 & 10000 & 10600 & 9300 & 9700 \\
\hline Poland & 5600 & 5500 & 5000 & 5300 & 6400 & 7100 & 8200 & 9500 & 8100 & 9300 \\
\hline Slovenia & 11500 & 12300 & 12900 & 13600 & 14400 & 15500 & 17100 & 18400 & 17300 & 17300 \\
\hline Slovakia & 4400 & 4800 & 5500 & 6300 & 7100 & 8300 & 10200 & 12000 & 11700 & 12100 \\
\hline
\end{tabular}

Source: Eurostat, National Accounts

For efficiency seeking investment it is more important the openness of the country and involvement in the international trade, than the purchasing power. There are two basic factors influencing the size of the involvement of a country in international trade:

- $\quad$ the size of a country (total population)

- the level of reached economic development

The following Table 5 includes indicators of the intensity of the engagement of countries in international trade, respectively the quantitative role of exports in the economy of a country. The openness of a country is important mainly in case of efficiency seeking investment. They are based on low cost production which is determined for export to abroad. Looking at indicators of the Czech Republic it is possible to comment a relatively high engagement in international trade comparing to other countries from the region. This kind of engagement represents of course high attractiveness for international investment.

Table 5: Exports of goods and services (\% of GDP)

\begin{tabular}{|l|l|l|l|l|l|l|l|l|l|l|}
\hline Country/Year & 2001 & 2002 & 2003 & 2004 & 2005 & 2006 & 2007 & 2008 & 2009 & 2010 \\
\hline EU-27 & 36.0 & 35.2 & 34.5 & 35.8 & 37.2 & 39.6 & 40.2 & 41.2 & 36.5 & 40.6 \\
\hline EU-15 & 35.4 & 34.7 & 33.7 & 34.8 & 36.2 & 38.5 & 39.0 & 40.0 & 35.3 & 39.3 \\
\hline Czech R. & 65.4 & 60.2 & 61.8 & 70.1 & 72.2 & 76.4 & 80.1 & 77.1 & 69.1 & 67.9 \\
\hline Hungary & 71.0 & 62.8 & 61.1 & 62.9 & 66.0 & 77.2 & 80.5 & 82.1 & 77.9 & 86.5 \\
\hline Poland & 27.1 & 28.6 & 33.3 & 37.5 & 37.1 & 40.4 & 40.8 & 40.0 & 38.9 & 42.3 \\
\hline Slovenia & 55.5 & 55.2 & 54.0 & 58.0 & 62.1 & 66.5 & 69.5 & 67.7 & 58.9 & 65.4 \\
\hline Slovakia & 72.8 & 71.2 & 75.9 & 74.6 & 76.3 & 84.4 & 86.7 & 83.0 & 70.1 & 81.2 \\
\hline
\end{tabular}

Source: Eurostat, National Accounts

Another indicator, which is the result of not only intensity, but also efficiency of the structure of foreign trade of a country, is so called transformation effect. The indicator is constructed as follows: the volume of exports of industrial products (SITC $5+6+7+8$ ) per capita minus import of raw materials, fuel and non-industrial products (SITC 0-3) per capita. This indicator in fact expresses the value added to import inputs. 
Table 6: Transformation Effect (USD per capita) ${ }^{1}$

\begin{tabular}{|l|l|l|l|l|l|l|l|l|l|l|}
\hline Country/Year & 2001 & 2002 & 2003 & 2004 & 2005 & 2006 & 2007 & 2008 & 2009 & 2010 \\
\hline Austria & 8632 & 8498 & 7199 & 7066 & 6923 & 7638 & 7648 & 7009 & 5993 & 6406 \\
\hline Germany & 6874 & 6720 & 5647 & 5654 & 5841 & 6412 & 6585 & 5930 & 5334 & 5989 \\
\hline Czech R. & 3136 & 3371 & 2966 & 3567 & 3851 & 4602 & 5091 & 5034 & 4368 & 5194 \\
\hline Hungary & 2834 & 3049 & 2681 & 2916 & 3017 & 3592 & 3854 & 3564 & 3209 & 3862 \\
\hline Poland & 768 & 827 & 767 & 871 & 1005 & 1260 & 1353 & 1370 & 1275 & 1407 \\
\hline Slovakia & 1859 & 2018 & 2318 & 2340 & 2559 & 3422 & 4303 & 4379 & 3967 & 4455 \\
\hline Slovenia & 4587 & 4688 & 3975 & 4185 & 4672 & 5362 & 6059 & 5607 & 4869 & 4872 \\
\hline
\end{tabular}

Source: Author's calculation on the basis of Eurostat

Evaluating the indicator of transformation effect reached in a longer period in new EU member countries, it is necessary to mention a relatively lower level in comparison to the small and developed old EU countries. For instance the Czech indicator represented only 36 $\%$ of the Austrian result or $46 \%$ of the German result in 2001. But a low efficiency of the foreign trade exchange turned to a positive trend, because the dynamic increase of transformation effect can be observed in the first decade of the new century. In 2010 the effect represented a much better result in the Czech case - an increase of indicator by nearly $66 \%$ against the level in 2001. This evolution is also connected to foreign investment, which increases the import of raw materials or semi-finished products as well as export of semifinished or finished goods.

\subsection{Labour market}

In the Czech Republic costs and productivity level attract mostly efficiency searching investments, which represent the big share of total investment inflow. The situation in the labor market is therefore important, especially for investment in industry. On the other hand investment in services is more focused on the domestic demand. Following tables summarize the basic characteristics of labour marker of the Czech Republic in the region.

The following Table 7 gives information on the level and changes over time of the unit labour costs in industry of selected countries. The indicator is calculated as average labour costs per 1 hour in industry measured in the Euro. In other words the indicator expresses wages per one hour in industry in the period from 2001 till 2007.

Table 7: Labour costs in EUR per country (average costs per 1 hour in industry)

\begin{tabular}{|l|l|l|l|l|l|l|l|l|l|l|}
\hline Country/Year & 2001 & 2002 & 2003 & 2004 & 2005 & 2006 & 2007 & 2008 & 2009 & 2010 \\
\hline EU-27 & 18.76 & 19.43 & 19.74 & 20.25 & 20.47 & 20.58 & 21.24 & 22.16 & 22.87 & 23.14 \\
\hline Czech Rep. & 4.64 & 5.39 & 5.47 & 5.85 & 6.63 & 7.14 & 7.88 & 8.78 & 8.65 & 9.09 \\
\hline Hungary & 4.04 & 4.91 & 5.10 & 5.54 & 6.14 & 6.34 & 7.13 & 7.63 & 7.88 & 7.91 \\
\hline Poland & 5.30 & 5.27 & 4.70 & 4.74 & 5.55 & 6.03 & 6.78 & 7.49 & 7.85 & 7.98 \\
\hline Slovakia & 3.26 & 3.59 & 4.02 & 4.41 & 4.80 & 5.33 & 6.41 & 0.25 & 8.08 & 8.04 \\
\hline Slovenia & 9.51 & 10.09 & 10.54 & 10.41 & 10.76 & 11.37 & 12.09 & 12.55 & 12.75 & 13.8 \\
\hline Germany & 25.60 & 26.20 & 26.80 & 26.90 & 27.10 & 27.60 & 27.80 & 28.94 & 29.52 & 29.52 \\
\hline
\end{tabular}

Source: Eurostat, Labour Market

Labour costs represent the clear competitive advantage, because their level is many times lower than the EU-15 average (and also the EU-27). With a little exception there is a clear trend of increasing labour costs in the given period, but the difference between new member countries is still very high and represents the important factor of competitiveness in the EU marketso far. In case of the Czech Republic the unit labour costs in industry reached only c.

\footnotetext{
${ }^{1}$ Transformation effect in USD $=$ exports per capita (SITC 5+6+7+8) minus imports per capita (SITC 0-3)
} 
$18 \%$ of German costs in 2001 and even if they increased by about $235 \%$ in 2010, they still represent only $31 \%$ of the German costs in the same year.

The indicator of unit labour costs does not eliminate the differences in labour productivity, even if the level of labour productivity represented the important factor explaining lower wages. The following Table 8 gives the overview of productivity indicators of selected countries.

Table 8: Labour productivity in industry $(\mathrm{EU}-15=100)$

\begin{tabular}{|l|l|l|l|l|l|l|l|l|l|l|}
\hline Country/Year & 2001 & 2002 & 2003 & 2004 & 2005 & 2006 & 2007 & 2008 & 2009 & 2010 \\
\hline Bulgaria & 28.6 & 30.4 & 31.2 & 31.3 & 32.4 & 33.0 & 34.1 & 36.1 & 36.6 & 37.9 \\
\hline Czech Rep. & 60.3 & 60.4 & 63.8 & 65.8 & 66.0 & 67.0 & 69.3 & 67.5 & 68.6 & 67.3 \\
\hline Germany & 94.4 & 94.6 & 96.7 & 97.0 & 98.2 & 98.4 & 98.4 & 98.3 & 95.9 & 96.5 \\
\hline Hungary & 54.7 & 57.8 & 59.2 & 60.4 & 61.2 & 61.4 & 60.9 & 64.6 & 65.9 & 65.2 \\
\hline Poland & 50.0 & 52.7 & 54.1 & 55.8 & 55.8 & 55.4 & 56.5 & 56.8 & 59.9 & 61.2 \\
\hline Slovenia & 67.7 & 69.2 & 70.8 & 73.5 & 75.2 & 75.5 & 75.5 & 76.4 & 73.9 & 73.7 \\
\hline Slovakia & 54.0 & 56.1 & 57.1 & 59.3 & 62.2 & 64.9 & 69.4 & 72.7 & 72.9 & 74.6 \\
\hline
\end{tabular}

Source: Eurostat, Labour Market

Figures in Table 8 are indexes of productivity of individual countries related to the average of EU-15 (EU-15 = 100\%). The higher the index over 100, the higher the productivity of the given country is over the EU-15 average and vice versa. On the basis of the indexes in Table 8 it is possible to conclude that the labour productivity of five member countries is much lower than the EU-15 average, even if the trend is increasing. The Czech data speak about nearly half level of the EU-15 average. The lower level of the labour productivity in member states is more than compensated with a much lower level of unit labour costs. The dis/advantage will be dependent on the rate of growth of wages and on the rate of increase in productivity level.

In the Czech case it is possible to conclude that the competitive advantage of lower costs is decreasing: unite wages increased by about $96 \%$ between the years 2001-2010, while the labour productivity increase was only $12 \%$ in the same period. The similar results are possible to be concluded from comparisons between the trend of increasing wages and increasing productivity - that means the increasing trend of unit labour costs is higher than the increasing productivity and the common result is the decreasing competitiveness coming from lower wages of the new EU member.

\subsection{Barriers of the free flow of FDI}

Investment flows are also affected by restrictions that prevent free movement of the capital between countries, acquisition of property or the ability to set up a company. To measure these barriers, OECD compiled the index that expresses the degree of protection of domestic markets from foreign investors. This index consists of four fundamental indicators restrictions or prohibitions on owning companies by foreign entities, vetting and approval process, restrictions on foreign management and other implementation constraints such as limits on purchases of land or repatriation of profits and capital (Kalinova, Palerm and Thomsen, 2010, pp. 9-14). Countries that are closed and prevent the flow of investments have an index of value 1, while the movement of investments without obstacles means the value 0 . Results for selected countries are shown in Table 9. 
Table 9: FDI index

\begin{tabular}{|l|l|l|l|l|l|}
\hline Country/Indicator & $\begin{array}{l}\text { Restriction of } \\
\text { owning }\end{array}$ & Permission & $\begin{array}{l}\text { Foreign } \\
\text { management }\end{array}$ & $\begin{array}{l}\text { Implementation } \\
\text { constraints }\end{array}$ & FDI Index \\
\hline Czech Republic & 0,049 & 0,000 & 0,000 & 0,006 & 0,055 \\
\hline Hungary & 0,065 & 0,000 & 0,000 & 0,001 & 0,066 \\
\hline Poland & 0,058 & 0,000 & 0,000 & 0,053 & 0,111 \\
\hline Romania & 0,008 & 0,000 & 0,000 & 0,000 & 0,008 \\
\hline Slovakia & 0,049 & 0,000 & 0,000 & 0,000 & 0,049 \\
\hline Slovenia & 0,011 & 0,000 & 0,000 & 0,000 & 0,012 \\
\hline
\end{tabular}

Source: OECD, 2012

The Czech Republic does quite well, compared to other countries in the region. There are virtually no restrictions on the special permits for foreign investors and restrictions on foreign management. Some obstacles can be found for companies owned by foreign entities and other implementing measures. But in general the FDI index is very low which means a high advantage for foreign investors.

\subsection{Governmental measures}

The government is predominantly involved in attracting investment into the country, mainly due to increased employment, domestic demand, the GDP and tax revenues. Therefore, the government tries to convince multinational companies to invest just in its country and it offers them various incentives.

The government's measures maybe an effective tool for enhancing investment. In particular, these are measures to strengthen financial system stability, to reduce taxes, to improve access to loans, etc. These measures are important not only in host countries, but also in the countries of the largest investors. Governments should also focus their support not only on new investors, but also on maintaining attracting existing investments in the country with more favourable measures.

\subsection{Risk}

Investors expanding their foreign activities take into account the overall country risk. The riskier country, the lower inflow and the higher benefits investors expect. The most important indicators are following: the economic stability of the country, the developed financial markets and the stability and sustainability of government deficits.

Table 10 shows the evaluation of risk according to the indicators of selected companies and organizations. All indicators show the country risk, namely its ability to fulfill international obligations, taking into account both the economic and political risk. The OECD divides countries into eight groups ( 0 -the best, 7 -the worst). Next three rating agencies divide the country into two groups - investment and speculative groups, which are further divided into twenty categories (Aaa, AAA - the best, Ca, SD -the worst). From these data it is obvious that the Czech Republic represents a very low risk for investment in the region and it is a relatively safe country for investors. 
Table 10: Risk of the country

\begin{tabular}{|l|l|l|l|l|l|l|l|}
\hline \multirow{3}{*}{ Country/Indicator } & \multicolumn{3}{l}{ OECD } & MOODY'S & $\begin{array}{l}\text { STANDARD } \\
\text { \& POOR'S }\end{array}$ & Fitch-IBCA \\
\cline { 2 - 8 } & 2007 & 2008 & 2009 & 2010 & 2010 & 2010 & 2010 \\
\hline Bulgaria & 3 & 3 & 4 & 4 & Baa3 & BBB & BBB- \\
\hline Czech Republic & 1 & 0 & 0 & 0 & A1 & A & A+ \\
\hline Hungary & 3 & 3 & $4 / 0$ & 0 & Baa1 & BBB- & BBB \\
\hline Poland & 2 & 2 & 2 & 2 & A2 & A- & A- \\
\hline Romania & 3 & 3 & 4 & 4 & Baa3 & BB+ & BB+ \\
\hline Slovenia & 0 & 0 & 0 & 0 & Aa2 & AA & AA \\
\hline Slovakia & 1 & 1 & 0 & 0 & A1 & A+ & A+ \\
\hline
\end{tabular}

Source: OECD, the Czech National Bank

\subsection{The exchange rate}

FDI are long term investments and therefore the exchange rate stability is important for them. It is an advantage, when the host country and investors use the same currency or at least currencies with a fixed exchange rate. Payables and receivables between the subsidiary and the parent company are then of the same value with no exchange rate risk.

In international statistic databases there is systematically monitored the indicator Real Effective Exchange Rate $^{2}$, as an indicator explaining and influencing competitiveness of countries. Conception of evaluating this indicator comes from the comparison of the changes in domestic and foreign prices multiplied by the change in nominal exchange rates of one (domestic) currency to the set (basket) of foreign currencies (Eurostat, 2012). The simple form of REER is as follows:

$\mathrm{REER}=\mathrm{E} . \mathrm{P}_{\mathrm{f}} / \mathrm{P}_{\mathrm{d}}$

where:

REER $=$ Real Effective Exchange Rate

$\mathrm{E}=$ Nominal Exchange Rate of domestic currency against foreign currencies

$\mathrm{P}_{\mathrm{f}}=$ Foreign Price Index

$\mathrm{P}_{\mathrm{d}}=$ Domestic Price Index

The above mentioned simple form is in calculation transferred into calculation of the complex form where important aspects are:

- $\quad$ the choice of foreign currencies coming into calculation,

- $\quad$ relevant weights of chosen currencies,

- the choice of the corresponding price index describing price trends (the consumer price index or the producer's price index or the export price index).

\footnotetext{
${ }^{2}$ The conception of REER has been developed after the collapse of Bretton-Woods system and start of floating exchange rates; the index is systematically calculated and published in OECD statistics and since certain time also in statistics of some central banks.
} 
Table 11: Real Effective Exchange Rate $(1999=100$, the chosen set of 36 countries for calculation)

\begin{tabular}{|l|l|l|l|l|l|l|l|l|l|l|}
\hline Country/Year & 2001 & 2002 & 2003 & 2004 & 2005 & 2006 & 2007 & 2008 & 2009 & 2010 \\
\hline EU-27 & 91.5 & 97.3 & 109.1 & 115.6 & 114.1 & 115.1 & 122.1 & 124.0 & 120.8 & 103.43 \\
\hline Czech R. & 110.0 & 127.9 & 129.8 & 131.3 & 137.5 & 145.1 & 150.0 & 170.7 & 163.8 & 151.84 \\
\hline Hungary & 113.9 & 129.4 & 132.9 & 141.5 & 146.0 & 137.7 & 150.0 & 152.3 & 137.3 & 139.08 \\
\hline Poland & 120.9 & 110.7 & 94.1 & 89.2 & 99.1 & 100.2 & 103.9 & 116.8 & 95.1 & 123.58 \\
\hline Slovakia & 107.0 & 110.2 & 119.1 & 127.5 & 135.0 & 140.9 & 153.4 & 168.9 & 187.0 & 192.02 \\
\hline Slovenia & 98.2 & 99.3 & 100.9 & 102.3 & 100.7 & 100.8 & 101.6 & 104.3 & 110.8 & 106.28 \\
\hline
\end{tabular}

Source: Eurostat, Exchange rates, 2010

The increasing REER index means the decrease in competitiveness due to either strengthening of nominal ER of the domestic currency or lower domestic inflation. This trend of indicator REER is clear in case of the Czech Republic, that means the decrease in competitiveness through strengthening of the nominal exchange rate and relative stability of domestic prices. The similar trend is also clear in case of the other new member countries with certain exceptions in certain years (Plchova, 2005).

\section{The competitiveness influencing the FDI flows}

In the following part the main aim is to compare the overall competitiveness of the Czech Republic to other countries with focus on some important areas. It should bring results for advantages and disadvantages not only in focus on some basic indicators (like in part 2), but it should focus more on the competitiveness of the whole sector - labour market, financial market, innovations, education etc. Multidimensional evaluations of international competitiveness represent complex evaluations on the basis of both quantitative and qualitative evaluations (often characterized as institutional aspects, evaluation on nonmaterial, non-costs basis). Two international institutions are systematically and regularly engaged in competitiveness evaluation in the international measure - the World Economic Forum (WEF, Geneva) and the Institute for Management Development (IMD, Lausanne).

Even if both are coming from the common multidimensional basis for competitiveness evaluation, the concept of perception of competitiveness is different. While IMD is more concentrated on indicators of the strength in international market competition, WEF takes more into account the rate of economic growth of a country (or the relevant subject of evaluation). Among critics against both competitiveness reports there are certain doubts about the method of collecting of "soft" data. There are doubts about the objectivity of the answers according to different importance or different interest of individual experts in the team of respondents.

WEF multidimensional evaluation system consists of 12 pillars influencing competitiveness results:

- Institutions

- Infrastructure

- Macroeconomic stability

- Health and primary education

- Higher education and training

- $\quad$ Goods market efficiency

- $\quad$ Labour market efficiency

- Financial market sophistication

- Technological readiness 
- $\quad$ Market size

- Business sophistication

- Innovation

IMD system of evaluation of international competitiveness, taken from the general outcome, is coming from two levels of evaluation:

- $\quad$ ability of individual countries and relevant business subjects to use its advantages to reach prosperity and profit in international competition,

- the complex of geographical, economic and social environment and policies, which form and influence the ability of business to reach prosperity and efficiency for keeping the living standard of people in the given country. The total set of more than 300 indicators is divided into 4 groups:

- macroeconomic efficiency,

- $\quad$ government efficiency,

- business efficiency,

- $\quad$ infrastructure (basic technological, research, human capital).

The following part of the study comes from the survey of competitiveness of selected 40 countries (the total WEF evaluated set of countries has been about 130) in the period of the last years.

Table 12: International Competitiveness Evaluation in WEF Reports

\begin{tabular}{|c|c|c|c|c|}
\hline Country/Year & $\begin{array}{l}\text { Order } \\
2009-2010\end{array}$ & $\begin{array}{l}\text { Order } \\
2008-2009\end{array}$ & $\begin{array}{l}\text { Order } \\
2007-2008\end{array}$ & $\begin{array}{l}\text { Order } \\
2006-2007\end{array}$ \\
\hline Switzerland & 1 & 2 & 2 & 4 \\
\hline USA & 2 & 1 & 1 & 1 \\
\hline Singapore & 3 & 5 & 7 & 8 \\
\hline Sweden & 4 & 4 & 4 & 9 \\
\hline Denmark & 5 & 3 & 3 & 3 \\
\hline Finland & 6 & 6 & 6 & 6 \\
\hline Germany & 7 & 7 & 5 & 7 \\
\hline Japan & 8 & 9 & 8 & 5 \\
\hline Canada & 9 & 10 & 13 & 12 \\
\hline Netherlands & 10 & 8 & 10 & 11 \\
\hline Hongkong & 11 & 11 & 12 & 10 \\
\hline Tchaj-wan & 12 & 17 & 14 & 13 \\
\hline Great Britain & 13 & 12 & 9 & 2 \\
\hline Norway & 14 & 15 & 16 & 17 \\
\hline Australia & 15 & 18 & 19 & 16 \\
\hline France & 16 & 16 & 18 & 15 \\
\hline Austria & 17 & 14 & 15 & 18 \\
\hline Belgium & 18 & 19 & 20 & 24 \\
\hline South Korea & 19 & 13 & 11 & 23 \\
\hline New Zealand & 20 & 24 & 24 & 21 \\
\hline Luxembourg & 21 & 25 & 25 & 25 \\
\hline Catarrh & 22 & 26 & 31 & 32 \\
\hline UAE & 23 & 31 & 37 & 34 \\
\hline Malaysia & 24 & 21 & 21 & 19 \\
\hline Ireland & 25 & 22 & 22 & 22 \\
\hline Island & 26 & 20 & 23 & 20 \\
\hline Israel & 27 & 23 & 17 & 14 \\
\hline Saudi Arabia & 28 & 27 & 35 & $\mathrm{xx}$ \\
\hline China & 29 & 30 & 34 & 35 \\
\hline Chile & 30 & 28 & 26 & 27 \\
\hline Czech Republic & 31 & 33 & 33 & 31 \\
\hline
\end{tabular}

Source: WEF, Global Competitiveness Report 
Among the first ten countries there are: the USA, Switzerland, Singapore, Sweden, Denmark, Finland, the Netherlands and in addition also Germany, Japan and Canada. In the second group there are EU countries such as: Great Britain, France, Austria, Belgium, Luxemburg and Ireland. Some EU old member countries reached position worse than 30. It concerns Spain, Portugal, Italy and Greece. The new member countries had the position around $40-50$ and more. Better positions among the new EU members were reached by the Czech Republic (ranks 33 - 31) and Slovenia (ranks 40 - 37) over last years.

WEF Reports evaluations are based on 12 pillars influencing competitiveness. The results of the total position of countries (the Global Competitiveness Index) and evaluation of individual pillars of selected groups of the new EU member countries is expressed in Table 13.

Table 13: GCI and Individual WEF Pillars Evaluation of the New EU Members

\begin{tabular}{|l|l|l|l|l|l|}
\hline \multirow{2}{*}{ Indicator/Country } & Czech Republic & Hungary & Poland & Slovenia & Slovakia \\
\cline { 2 - 6 } & $2009-2010$ & $2009-2010$ & $2009-2010$ & $2009-2010$ & $2009-2010$ \\
\hline GCI & 31 & 58 & 46 & 37 & 47 \\
\hline Basic conditions & 45 & 58 & 71 & 29 & 54 \\
\hline Institutions & 62 & 76 & 66 & 46 & 78 \\
\hline Infrastructure & 48 & 57 & 103 & 31 & 63 \\
\hline Macroeconomic stability & 43 & 83 & 74 & 26 & 40 \\
\hline Health and primary education & 33 & 53 & 35 & 22 & 48 \\
\hline Efficiency & 24 & 45 & 31 & 37 & 34 \\
\hline Higher education and training & 24 & 35 & 27 & 19 & 47 \\
\hline Goods market efficiency & 27 & 64 & 53 & 38 & 32 \\
\hline Labour market efficiency & 20 & 63 & 50 & 56 & 29 \\
\hline Financial market sophistication & 42 & 69 & 44 & 48 & 28 \\
\hline Technological readiness & 30 & 40 & 48 & 32 & 33 \\
\hline Market size & 40 & 45 & 20 & 72 & 57 \\
\hline Innovations and sophistication & 26 & 61 & 46 & 30 & 57 \\
\hline Business sophistication & 25 & 76 & 44 & 33 & 51 \\
\hline Innovations & 25 & 45 & 52 & 29 & 68 \\
\hline
\end{tabular}

Source: WEF, Global Competitiveness Report

Comparing the inter-country differences in the region it is possible to conclude:

The Czech Republic reached the best position in the complex evaluation in GCI;

In the pillar Institutions all evaluated countries reached very bad results;

In the pillar Infrastructure the best results were reached by Slovenia (36-31) and the Czech Republic (50-48);

In the pillar Health and primary education Slovenia (21-22) and the Czech Republic (29-33) had the best results;

Similar evaluation was in the pillar Higher education: the best positions were reached by Slovenia (22-19) and the Czech Republic (25-24).

The pillar Goods market efficiency had the best results in the Czech Republic (33-27) and in Slovakia (35-32);

The evaluation of the efficiency of labour market was similar: in the Czech Republic ranks 28-20, in Slovakia ranks 36-29; 
The best level of financial market sophistication had Slovakia (31-28); much worse is the rank for the Czech Republic (47-42);

The best technological readiness was reached by the Czech Republic (33-30) and Slovenia (30-32);

The level of market business sophistication was the highest one in the Czech Republic (29-25) and in Slovenia (34-33);

Innovation level was evaluated as the highest one in the Czech Republic (25) and in Slovenia.

\section{Conclusion}

The Czech Republic has been registering a strong inflow of foreign capital. At the beginning FDI inflows to the Czech Republic accounted mostly for investment in equity, but over time the importance of reinvested earnings and other capital, which represented a financial transaction between the parent company and the subsidiary, began to grow significantly. On the contrary, investments in equity have been falling. From the overall analysis of the competitiveness and also from the individual indicators, it is possible to conclude that the Czech Republic is attractive especially for efficiency seeking investment. Even if the evaluation of the competitiveness of the Czech Republic reaches low position in the total set, in reality there are proofs of stronger real competitiveness in comparison to figures coming from WEF or IMD indicators. And what is clear from trends - the situation is improving. The Czech Republic gets a very good evaluation of competitiveness compared to other countries in the region. It has an educated and efficient workforce, efficient goods market, developed technological readiness and innovations. The only problem is that the financial market sophistication is not so developed. But it is important to mention that some indicators are based on the subjective evaluation and therefore the ranking of countries can be in some aspects controversial. The openness of the country is very important for the FDI and also the inflow of foreign capital makes the country more and more open, as it is connected with the increase of import as well as export. Despite the decreasing advantage of low labour costs, the country is still very interesting for foreign investors as it can also provide low risk and high stability, comparing to the other countries in the region with low labour costs. Moreover, the country is attractive for investors with no barriers for FDI inflow and governmental measures supporting direct investment. Finally it is also important to mention that the high inflow of foreign investment provides a high stimulus for the economy, which increases also the overall competitiveness of the country.

\section{References}

[1] ČAPEK, A., M. HÁJEK a P. MERTLÍK, 2002. Konkurenceschopnost české ekonomiky. Prague: Universtiy of Economics. ISBN 80-210-4157-9.

[2] EUROSTAT, 2012. Effective exchange rate indices [online]. July 2012 [10-10-2012]. Available at: http://epp.eurostat.ec.europa.eu/cache/ITY_SDDS/EN/ert_eff_esms. htm\#meta_update

[3] FILIPPOV, S. and K. KALOTAY, 2009. "Foreign Direct Investment in Times of Global Economic Crisis: Spotlight on New Europe." UNU-MERIT Working Papers, 21. ISSN 1871-9872.

[4] INTERNATIONAL MONETARY FUND, 1995. Balance of Payments Manual. 5.ed. Washington: International Monteray Fund. ISBN 1-55775-339-3. 
[5] JIRÁNKOVÁ, M., 2007. Konkurenceschopnost zemí EU a České republiky z pohledu Světové ročenky konkurenceschopnosti. Současná Evropa a Česká republika, 12(2), 206-237. ISSN 1211-4073

[6] KALINOVA, B., A. PALERM and S. THOMSEN, 2010. OECD's FDI Restrictiveness Index: 2010 Update." OECD Working Papers on International Investment, 3(25).

[7] KALOTAY, K., 2006. New Members in the European Union and Foreign Direct Investment. Thunderbird International Business Review, 48(4) 485-513. ISSN 10964762 .

[8] KÄRKKÄINEN, A., 2008. EU-15 Foreign Direct Investment in the new Member States. EUROSTAT Statistics in focus. Economy and finance, 714. ISSN 977-0316.

[9] KLVAČOVÁ, E., 2002. Konkurenceschopnost národních ekonomik: podstata, měření, problem, vypovídaci schopnost. Prague: Univesity of Economics.

[10] KUBIŠTA V., 2000.Vybrané problémy vývoje konkurenceschopnosti české ekonomiky $v$ mezinárodním srovnání. Prague: Univestiy of Economics. ISBN 80-238-5048-2

[11] NEŠVERA, V., 1999. Konkurenční schopnost České republiky. 1. ed. Prague: University of Economics. ISBN 80-7079-670-7.

[12] PLCHOVÁ, B., 2005. Vybrané aspekty vývoje konkurenceschopnosti C̆R. Acta Oeconomica Pragensia, 13(1). ISSN 0573-3043.

[13] POLÁCHOVÁ, M., 2009. Hodnocení konkurenceschopnosti $\check{C} R$. Prague: Univesity of Economics.

[14] PRICEWATERHOUSECOOPERS, 2010. Foreign Direct Investment in Central and Eastern Europe.A case of boom and bust? Prague: PWC.

[15] TURNER, P., VAN`TDACK, 1993. Measuring International price and Cost Competitiveness. Basel: BIS. ISBN 92913103799789291310371.

[16] UNCTAD, 2009. Assessing the impact of the current financial and economic crisis on global FDI flows. Geneva: UNCTAD.

[17] UNITED NATIONS, 2008. World Investment Report 2008. Transnational Corporations and the Infrastructure Challenge. New York and Geneva: United Nations. ISBN 978-92-1-112755-3.

[18] UNITED NATIONS, 2009.World Investment Report 2009. Transnational Corporations, Agricultural Production and Development. New York and Geneva: United Nations. ISBN 978-92-1-112775-1.

[19] UNITED NATIONS, 2010. World Investment Report 2010. Investing in a LowCarbon Economy. New York and Geneva: United Nations. ISBN 978-92-1-112806-2. 